\title{
On the acquisition of French speech rhythm in a multilingual classroom: Evidence from linguistic and extra-linguistic data
}

\author{
Christoph Gabriel, Johanna Stahnke \& Jeanette Thulke \\ University of Hamburg, Department of Romance Studies \\ christoph.gabriel@uni-hamburg.de,johanna.stahnke@uni-hamburg.de, jeanette.thulke@uni-hamburg.de \\ Christoph Gabriel \\ University of Hamburg, Department of Romance Studies \\ christoph.gabriel@uni-hamburg.de
}

\section{Introduction}

There can no longer be any doubt that linguistic and cultural diversity have become an important prerequisite in foreign language learning and teaching all over the world. This also holds true for presentday school settings in urban spaces in Germany, where roughly a third of all children have a migration background and grow up with more than one language (see, e.g., Elsner 2010: 99). The aims of foreign language instruction consequently have become more diverse, i.e., in addition to communicative skills in the foreign languages taught, plurilingual competencies as well as metalinguistic and language learning awareness have recently gained more and more in importance.

Foreign language learning (FLL) is by nature linked to phenomena of cross-linguistic influence. Consequently, foreign language production is usually characterized by negative or positive transfer from a native to a non-native system. We adopt the widely accepted definition of transfer proposed by Odlin (1989) who speaks of "the influence resulting from the similarities and differences between the target language and any other language that has been previously (and perhaps imperfectly) acquired" (27; see also Odlin 2003 for an overview). Negative transfer qualifies as the non-target-like transference of a linguistic structure to a second or foreign language; the notion of positive transfer, by contrast, is to be understood as the target-like production of a certain property of the language learned that corresponds to some parallel structure of the learners' linguistic background (comprising both their native tongue and any other language acquired beforehand). A large number of studies on transfer deal with cross-linguistic influence between typologically related languages, mostly from a language pedagogical point of view (e.g., Martinez \& Reinfried 2006, Mehlhorn 2008, Meißner \& Reinfried 1998). However, the influence of typologically distant heritage languages (HL) has long been disregarded with respect to the learning of further languages, in both linguistics and language pedagogy (Hu 2011). In particular, this applies to the field of suprasegmental phonology, despite the fact that prosody has been shown to considerably contribute to the perception of foreign accent (Boula de Mareüil \& Vieru-Dimulescu 2006) and thus should be of special interest for the teaching of foreign languages. At least some recent studies on FLL by multilingual learners address Turkish as a HL (see, e.g., Elsner 2007 and Rauch et al. 2010 on the learners' reading and understanding competencies in both their HL and the foreign language English, as well as Sağin Şimşek 2006 and Kupisch, Snape \& Stangen 2013 on word order and use of determiners in L2 English). However, typologically distant HLs such as Mandarin Chinese have not yet been dealt with in the literature, nor have foreign languages other than English been addressed so far.

Our contribution investigates the acquisition of French speech rhythm by German senior high school students with HL Mandarin Chinese. We thus address a group of immigrants that make up large communities in today's urban spaces in Europe, but are almost completely disregarded in both linguistic research and language pedagogy, presumably not least because of the educational success of Chinese immigrants' children. We focus on rhythmic transfer, thereby concentrating on the question of to what extent the languages constituting the learners' linguistic background, i.e., German as the surrounding and 
dominant language and the HL Mandarin Chinese, serve as a basis for (positive or negative) transfer in the acquisition of French timing patterns. We explicitly combine phonetic and educational perspectives, aiming at answering the question of if extra-linguistic factors such as the learners' attitudes towards their background languages (German and Mandarin Chinese) on the one hand and the foreign language French on the other as well as their individual degree of multilingual and phonological awareness have an effect on the acquisition of speech rhythm in FLL. ${ }^{1}$

The paper is organized as follows: In section 2, we characterize the languages under discussion from a typological perspective, focusing on the similarities and differences between German, the HL Mandarin Chinese and the foreign language French. In a next step, we offer a brief overview of current research on speech rhythm, thereby focusing on rhythmic transfer in multilingual settings (section 3 ). In section 4 , we provide the reader with information on our experimental design, then present the results and finally discuss them with special interest given to interrelations between linguistic and non-linguistic factors constraining the acquisition of speech rhythm in FLL. A summary of the findings and some concluding remarks are offered in section 5 .

\section{Is Mandarin Chinese really different?}

Seen from an Indo-European perspective, Mandarin Chinese seems to be maximally distant from both German (language of instruction at school and surrounding language) and the foreign language French. A striking feature of 'otherness' is related to the use of totally different writing systems: While Mandarin Chinese makes use of a basically logographic script, the so-called 汉字 hànzi 'Chinese characters', which represent meaningful units (i.e., lexical or functional morphemes) and thus refer to the semantic level of the language, the Latin script used for German and French refers to the phonological level, essentially relying on phoneme-grapheme correspondences. The visually perceivable distance between Mandarin Chinese on the one hand and German and French on the other is mirrored in the genealogical relationship between the languages concerned: As a language of the Sino-Tibetan type, Mandarin Chinese is the only language of our sample that does not belong to the Indo-European group. Regarding morphosyntactic typology, Mandarin Chinese is once again set apart from the other languages due to its isolating grammar that contrasts with the inflecting-fusional structures of German and French. ${ }^{2}$ At first sight, this also holds for prosody, ${ }^{3}$ given that Mandarin Chinese qualifies as a tone language, allowing for the expression of lexical contrasts in monosyllabic and segmentally identical words by means of movements of fundamental frequency (F0), while both German and French belong to the group of so-called "intonationonly languages" (Gussenhoven 2004: 12), which lack tonal marking of semantic contrasts on the word level. Instead, German and French systematically use fundamental frequency (F0) for the marking of clause typing (e.g., declarative vs. interrogative intonation), for prosodic phrasing, and for the expression of paralinguistic meaning such as emotions. ${ }^{4}$ However, as soon as the durational properties of the languages under investigation are taken into account, the picture considerably changes, inasmuch as the syllable-timed speech rhythm of Mandarin Chinese (Lin \& Wang 2007) patterns with French, but contrasts with stress-timed German (see section 3). With this in mind, it is expectable that monolingual learners with L1 German (negatively) transfer the stress-timed speech rhythm of their mother tongue to the foreign language French, thus yielding a non-target-like production in the foreign language with respect to basic durational properties. By contrast, learners of French with Mandarin Chinese as an L1 or HL should perform more target-like concerning the production of the syllable-timed rhythm of French than monolingual German learners, since they may rely on positive transfer from their linguistic background to the foreign language.

\section{Approaching speech rhythm}

Apart from intonation, the prosodic shape of a given language is essentially determined by languagespecific timing patterns, i.e., by the systematic use of durational cues (speech rhythm). In what follows we offer a brief overview of the research on speech rhythm, thereby briefly characterizing the languages 
addressed in our study with respect to their rhythmic properties (section 3.1), before summarizing recent studies on rhythmic transfer in different situations of linguistic contact and FLL.

\subsection{From the classical rhythm typology to interval-based rhythm metrics}

According to the traditional dichotomy established by Pike (1945) and Abercrombie (1967), the languages of the world are classified as belonging to either the stress-timed or the syllable-timed group of languages. ${ }^{5}$ From this point of view, the perceivable contrast between the two types of languages is interpreted as a reflex of the isochrony of timing intervals: In syllable-timed languages, among them French and Mandarin Chinese, syllabic units tend to be of equal durations, whereas stress-timed languages such as German present stress-delimited feet of the same length, i.e., these languages exhibit approximately equal durations between the onsets of stressed syllables. After it was shown by scholars such as Roach (1982) and Dauer (1987) that neither syllable-based nor stress-based isochrony was systematic in either of the two groups of languages, research on speech rhythm largely developed in two different directions: A first line of investigation primarily relies on phonological features and interprets the durational properties of a given language as a surface reflex of its phonological properties, among them syllable structure (i.e., the degree of complexity of the syllabic constituents) and the presence or absence of vowel reduction (Dasher \& Bolinger 1982, Dauer 1987, Auer \& Uhmann 1998, Auer 2001). A second approach is rather phonetically oriented and concentrates on the ratio of vocalic (V) and consonantal (C) intervals in the speech signal (Dellwo 2006, Dellwo \& Wagner 2003, Grabe \& Low 2002, Ramus et al. 1999, White \& Mattys 2007). These surface-based approaches are largely based on the findings by Mehler et al. (1996), who showed that infants perceive the speech signal mainly as a sequence of $\mathrm{V}$ and $\mathrm{C}$ intervals that do not necessarily map with syllabic boundaries. ${ }^{6}$ Based on this assumption, Ramus et al. (1999) suggested that syllables should no longer be seen as the basic timing unit of a given language, but rather vocalic and intervocalic, i.e., consonantal intervals. Seen from this angle, the difference between stress- and syllable-timedness is evidenced by different proportions of vocalic material in the stretch of speech analyzed (\%V; Ramus et al. 1999) as well as by the values depicting the durational variability of $\mathrm{V}$ and $\mathrm{C}$ intervals (so-called rhythm metrics): The non-normalized metrics $\Delta \mathrm{V}$ and $\Delta \mathrm{C}$, as proposed by Ramus et al. (1999), simply express the standard deviation of vocalic and consonantal intervals, respectively. The variation coefficients VarcoV/C are speech-rate-normalized versions of $\triangle \mathrm{V} / \mathrm{C}$ (Dellwo \& Wagner 2003); the pairwise variability index (PVI), introduced by Grabe \& Low (2002), finally, differs from the aforementioned metrics in computing the durational variability in successive intervals instead of calculating it over the whole speech signal analyzed.

\subsection{Speech rhythm in FLL, bilingualism, and contact varieties}

In the past decade, the interest in the rhythmic properties of non-native speech and contact varieties has considerably increased. Regarding the context of FLL, transfer of the durational properties from a native to a non-native system has been attested in several studies, addressing different pairs of languages that belong to different rhythmic classes (e.g., stress-timed L1, syllable-timed foreign language), but also in work on the learning of a second or foreign language belonging to the same group as the native language of the learners. As for transfer across rhythmic classes, Pulzován de Egger (2002) has evidenced rhythmic transfer in non-native speech produced by German learners of Spanish and, vice versa, by (Argentinean) Spanish learners of German. The same effect was shown to occur in the data produced by Chinese learners of English as a foreign language (Chen 2012, Li \& Post 2012). Regarding transfer of durational properties in the context of FLL involving an L1 and a target language belonging to the same rhythmic group, transfer has been shown to occur, e.g., in German learners of English (Ordin et al. (2011) and in Italian learners of (Castilian) Spanish (Benet et al. 2012, Gabriel \& Kireva 2014); see also Gut (2011) for an overview.

Rhythmic transfer also occurs in the speech produced by adult bilingual speakers, as shown by White \& Mattys (2007) for Spanish/English and Spanish/Dutch bilinguals. A comparable effect has been 
evidenced in the field of bilingual L1 acquisition, e.g., by Kehoe et al. (2011), who compared the data gathered from Spanish/German bilingual children with control material produced by monolingual Spanish and German children.

As for the domain of (usually migration-induced) linguistic contact, rhythmic transfer has been attested for several Asian varieties of English in contact with syllable-timed languages, among them Mandarin Chinese (Low et al. 2000, Deterding 2001, Jian 2004, Setter 2006) and Hindi (Krivokapić 2013), for the varieties of French spoken in the Parisian banlieues ('suburban spaces'), which interact with migration languages such as Arabic (Fagyal 2010), and for Argentinean Spanish in contact with Italian (Benet et al. 2012, Gabriel \& Kireva 2014).

However, studies that explicitly deal with the acquisition of the speech rhythm of a foreign language by multilingual learners in an instructed learning setting are virtually inexistent, apart from a small pilot study by Gabriel et al. (2012) on the acquisition of French as a foreign language by multilingual learners with HL Mandarin Chinese. The results obtained in this study, albeit on a small data set and without taking into account relevant monolingual control data, indicate that learners with a syllable-timed language in their linguistic repertoire might benefit from the rhythmic properties of their HL regarding the acquisition of the syllable-timed rhythm of French via positive transfer. Our empirical study aims to corroborate the preliminary findings obtained in Gabriel et al. (2012) by relying on a larger data base and by including control data from monolingual Chinese learners of French, thus filling a gap in research in this field.

\section{Empirical study}

In the following section, we present the empirical study carried out with multilingual and monolingual learners of French as a foreign language. After introducing our hypotheses (section 4.1), we describe the experimental setting and the data collection (section 4.2) before presenting the results obtained from the analyses performed on the speech data (section 4.3) and finally discuss them (section 4.4).

\subsection{Hypotheses}

As pointed out in section 2, Mandarin Chinese considerably differs from both German and French. Speech rhythm, however, is an exception in this respect since Mandarin Chinese patterns with French regarding the syllable-timed rhythm of both languages. Based on the durational similarities between the foreign language French and their HL Mandarin Chinese, the multilingual learners might be advantaged over the German monolinguals regarding the target-like production of French speech rhythm in that they can rely on their linguistic background as a base for positive transfer from their (syllable-timed) HL to the (also syllable-timed) foreign language. Taking into consideration, however, that we are not dealing with a heterogenic group of balanced bilinguals, but rather with a subset of individual learners, whose linguistic biographies considerably differ from speaker to speaker, this hypothesis is likely to be only partially supported and thus needs to be modified. Apart from the learners' multilingual background, the variable status of both Mandarin Chinese and German needs to be taken into account: From learner to learner, both languages can be either the native language, an L2, or an early acquired L2, depending on the learner's linguistic biography. Furthermore, the age of learning of the foreign language French slightly varies from subject to subject, and some of the participants have learned further foreign languages in addition to English (their first foreign language) and French (see section 4.2 for a detailed description of the learners). A high degree of diversity also shows up with respect to the learners' individual attitudes towards the languages of the sample, and they might also differ regarding their individual degree of multilingual and phonological awareness. Due to these extra-linguistic factors, it is expected that the speech data produced by the multilingual learners present certain inconsistencies that can hardly be explained by referring only the rhythmic properties of the languages involved, but rather require that the 
aforementioned extra-linguistic factors be taken into consideration. Based on these prerequisites, we form the following two hypotheses:

(H1) The multilingual learners with a Mandarin Chinese and German language background produce the speech rhythm of the foreign language French in a more target-like way than the monolingual German learners do (because these lack any experience with syllable-timed languages).

(H2) Possible inconsistencies in the results obtained from the rhythmic analysis performed on the French data produced by the multilingual learners can be traced back to extra-linguistic factors.

\subsection{Methodology}

The set of test persons consists of one experimental group and three control groups. The experimental group comprises 13 multilingual students from a German senior high school, who all have started to learn English as a foreign language before French as a second formally instructed foreign language. At the moment of the data collection, they were aged 14-18 and had learned English for 5-11 years and French for 2-6 years. Table 1 gives an overview of the individual linguistic biographies of the informants, thereby clearly revealing the heterogeneity of the group of multilingual learners. Although most of them had acquired Mandarin Chinese or another Chinese language such as Cantonese, 潮州市话 Cháozhōu huà (a variety belonging to the 闽 Mŭn group), or 上海话 Shànghăi huà (吴 Wù group, Kurpaska 2010ff), and German as their native language (L1) or as an early L2, the ages of onset for the languages considerably differ from speaker to speaker (see table 1).

Table 1: Linguistic biographies of the multilingual learners (experimental group). (AoL = age of learning, $\mathrm{m}=$ male, $\mathrm{f}=$ female; $\mathrm{MAN}=$ Mandarin Chinese, $\mathrm{GER}=$ German, $\mathrm{CANT}=$ Cantonese, $\mathrm{ENG}=$ English, FRE $=$ French, SPA $=$ Spanish, RUS $=$ Russian)

\begin{tabular}{|l|l|l|l|l|l|l|}
\hline $\begin{array}{l}\text { Learner (age, } \\
\text { sex })\end{array}$ & L1 $(<3$ years $)$ & \multicolumn{2}{l}{ L2 + and foreign languages (AoL) } \\
\hline C01 $(17, \mathrm{f})$ & MAN & GER (9) & ENG (10) & FRE (11) & & \\
\hline C02 $(14, \mathrm{~m})$ & MAN, GER & ENG (9) & FRE (12) & & & \\
\hline C03 $(17, \mathrm{~m})$ & MAN & GER (6) & ENG (9) & FRE (12) & & \\
\hline C06 $(17, \mathrm{f})$ & CANT, GER & MAN (6) & ENG (9) & FRE (12) & & \\
\hline C08 (17, m) & GER, Cháozhöu huà & ENG, MAN (11) & FRE (13) & & & \\
\hline C09 (18, m) & MAN & ENG (10) & GER (12) & FRE (15) & & \\
\hline C10 (16, m) & CANT, GER & ENG, MAN (10) & FRE (11) & & & \\
\hline C12 (14, f) & MAN, GER & ENG (8) & FRE (10) & & & \\
\hline C13 (18, m) & MAN, GER & ENG (10) & FRE (13) & & & \\
\hline C14 (15, f) & MAN, GER & ENG (9) & FRE (11) & SPA (13) & & \\
\hline C15 (15, f) & Shànghăi huà, GER, MAN & ENG (8) & FRE (11) & SPA (13) & & \\
\hline C16 (17, f) & MAN & RUS (5) & ENG (6) & GER (9) & FRE (11) & SPA (13) \\
\hline C17 (16, f) & GER & MAN (5) & ENG (8) & FRE (11) & SPA (13) & \\
\hline
\end{tabular}

The first control group comprises ten monolingual German learners, all of whom are senior high school students (aged 15). At the time of the recordings (Hamburg 2012), they had learned English for seven years and French for four years. The second control group consists of ten monolingual Chinese senior high school students from Beijing. At the time of the data collection (Beijing 2012), their ages ranged 
between 17-21 years and they had learned English for 9-13 years and French for 1-6 years. All learners were recorded both in their mother tongue (German or Mandarin Chinese) and in the foreign language French. ${ }^{7}$ The native control data for French were gathered from ten students from the Université Michel de Montaigne (Bordeaux 3), all of them native speakers of Standard French (ages 18-22; recordings Bordeaux 2012).

From all test persons we collected both linguistic and non-linguistic data. Regarding the recordings of the speech data, we used three different types of material the participants were asked to read aloud. For each language, the materials comprise (1) a reading text, (2) a set of 13 sentences consisting of consonant vowel (henceforth: CV) syllables only, and (3) ten nonce words embedded in language-specific carrier dialogues. Concerning the reading text for German and Mandarin Chinese, we used the fable The North Wind and the Sun in its respective translations, i.e., Nordwind und Sonne and 北风和太阳 Běifêng hé tàiyáng. Due to the high degree of lexical difficulties contained in the French version of the fable (La bise et le soleil), the learners read a short story taken from a school textbook (Amandine fait du sport, see Jouvet 2006: 7). All the texts were controlled for syllable structure to ensure that the occurrences of different syllable types contained in the individual texts correspond to what is typical of the relevant language in regular speech. The second type of material comprises 13 short sentences for German, French, and Mandarin Chinese consisting exclusively of CV sequences. These were created to exclude the determining factor of syllable structure, i.e., to detect whether there are rhythmic differences between the languages of our sample that are independent of language-specific constraints on syllable structures. An example for each of the languages is given in (1-3), below.

GER Gero mähte die Wiese. [ge.во.me..tb.di.vi.zə] 'Gero mowed the meadow.'

MAN 哥哥不是理发师。(Gēge bú shì lǐfàshī.) [kə.kə.pu.ş li.fa.ş]

'The (elder) brother is not a hairdresser.'

FRE Le chat s'est caché sous le lit. [lə.ja.se.ka.fe.su.lə.li]

'The cat hid under the bed.'

As a third reading task, we created segmentally identical nonce words, integrated in language-specific carrier dialogues. The nonce words aimed at excluding the factor of intrinsic vowel length (Lehiste 1970), i.e., at neutralizing even more potential effects of language-specific phenomena on the durational properties of the languages involved. An example for each of the languages is given in (4-6), below.

GER (interviewer) Was hast du gegessen?

(learner) Ich hab ein Gericht gegessen, das Latimo Bolegamo heißt.

'What did you eat? I had a dish called Latimo Bolegamo.'

MAN (interviewer) 你吃了什么? Nĩ chī le shén me? (learner) 我吃了一道菜。它的名字是 lātīmò bólègámò。

Wŏ chī le yī dào cài. Tā de míngzi shì lātīmò bólègámò.

'What did you eat? I had a dish called lātīmò bólègámò.'

FRE (interviewer) Qu'est-ce que tu as mangé ?

(learner) J'ai mangé un plat qui s'appelle Latimeau Bolégameau.

'What did you eat? I had a dish called Latimo Bolegamo.'

For the analysis of the speech data, we measured all $\mathrm{C}$ and $\mathrm{V}$ intervals using Praat (Boersma \& Weenink 2011). ${ }^{8}$ Silent pauses and disfluent material were not considered for the analysis. Based on the segmentation described so far, we calculated $\% \mathrm{~V}$ and VarcoV using the computer software Correlatore (Mairano \& Romano 2010).

Regarding the collection of non-linguistic data, all learners - the monolinguals as well as the multilinguals - were asked to fill in a questionnaire in order to obtain data about their linguistic biographies. With the group of the multilingual learners, we also conducted semi-structured interviews 
(Kvale 2007), with special emphasis given to the learners' attitudes towards their languages as well as to their individual degree of metalinguistic and phonological awareness. ${ }^{9}$ With three of these speakers, we additionally carried out so-called think-aloud protocols (Osburne 2003) that aimed at getting information on the learners' perception and their knowledge about their own speech production in the foreign language French. To that end, the participants were first asked to distinguish an L1 from an L2 recording by explaining their decision. Furthermore, they read a set of sentences with language-specific phonological phenomena at their best French. After reading, they were asked to reflect on their own pronunciation and the problems they encountered. Table 2 summarizes the extra-linguistic data collected from the participants.

Table 2: Number of participants per group in extra-linguistic data collection

\begin{tabular}{|lc|c|c|}
\cline { 2 - 4 } \multicolumn{1}{c|}{} & questionnaire & interview & think-aloud protocol \\
\hline multilinguals (13) & 13 & 13 & 3 \\
\hline monolingual German (10) & 10 & - & - \\
\hline monolingual Chinese (10) & 10 & - & - \\
\hline monolingual French (10) & 10 & - & - \\
\hline
\end{tabular}

Regarding the non-linguistic data, we conducted a qualiltative analysis: We first created individual learner profiles based on the information taken from both the questionnaires and the interviews. In a second step, we extracted relevant passages from the interviews revealing the learners' attitudes towards their languages and their individual degrees of multilingual and phonological awareness (for examples see section 4.3). For the analysis of the think-aloud protocols, all instances of comments made by the learners were considered and classified depending on categories such as the production of segments and consonant clusters in the foreign language, the distinction between phonetic and the graphematic levels, intonation, word and sentential stress, information structure, speech rhythm, syllable optimizing processes (e.g., French liaison), and, finally, further prosodic parameters such as speech rate and intensity. The decision for this classification is derived from what the speakers said during the session. When one category was mentioned, it was counted for the analysis without taking qualitative differences into account; i.e., the think-aloud protocols have so far only been analyzed in an exclusively quantitative way. In the end, we identified interrelations between the linguistic and the non-linguistic data.

\subsection{Results}

Figure 1 illustrates the results obtained from the rhythmic analysis performed on the recordings of the read texts. The $\mathrm{x}$-axis indicates the percentage of vocalic material in the speech signal $(\% \mathrm{~V})$, while the $\mathrm{y}$ axis depicts the values for the variability of $\mathrm{V}$ intervals (VarcoV). For clarity, the L1 values for all languages are represented as averages from all speakers' results. All L1 values largely confirm what is reported in previous cross-linguistic studies (Ramus et al. 1999, Grabe \& Low 2002, Dellwo 2006, Mairano \& Romano 2010): Mandarin Chinese (right-sided triangle) exhibits a higher value for $\% \mathrm{~V}$ and a lower value for VarcoV as compared to German (left-sided triangle). The value for native French (rhombus, target value) is located in between the values for native German and native Mandarin Chinese with a slightly lower value for $\% \mathrm{~V}$ than Chinese and a lower value for VarcoV than German. Turning to the results of the learners, it is noteworthy that most of the learners display quite high values for both metrics when they speak French as a foreign language. We further see that the monolingual German learners (light grey squares) represent the group with the highest values for VarcoV, while the monolingual Mandarin Chinese learners (dark grey circles) obtain lower (and more target-like) values in this respect. The values for the multilingual learners (black triangles) are situated in between the two groups of monolingual learners. As for $\% \mathrm{~V}$, all of the three groups show a roughly comparable range of dispersion, while for the monolingual Chinese the range of VarcoV is slightly reduced in comparison with 
the others. Despite the fact that all groups can generally be distinguished from each other, some individual speakers display more target-like results than others do. For illustration, we highlight four speakers $(\mathrm{C} 01, \mathrm{C} 15, \mathrm{C} 16, \mathrm{C} 17)$ as examples for variable success regarding the production of speech rhythm in the target language. These four cases will be discussed in more detail when taking a closer look at the non-linguistic data.

Figure 1: \%V and VarcoV for the read texts.
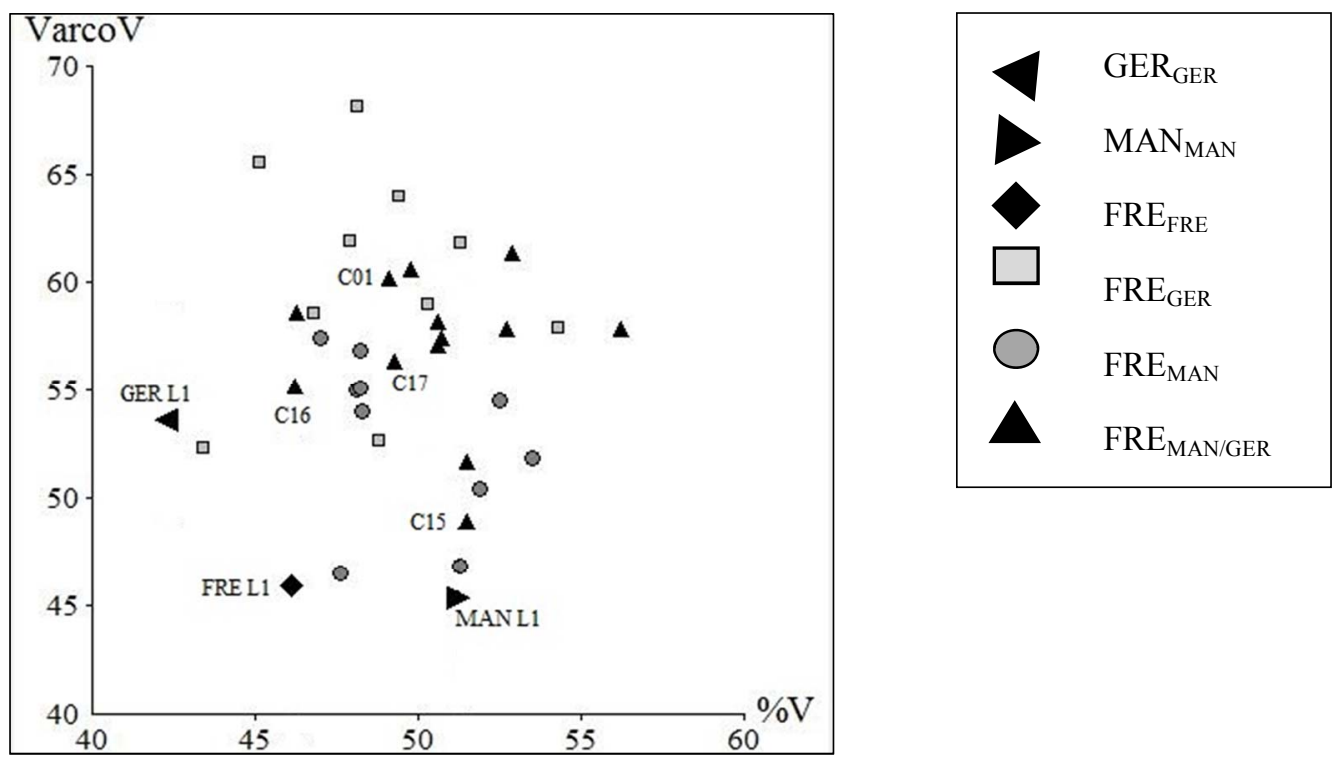

Figure 2 illustrates the results for the CV sentences. For native French and Mandarin Chinese, the values are comparable to those already obtained from the read texts (see Figure 1). For native German, in contrast, both VarcoV and $\% \mathrm{~V}$ have changed so that German appears to be comparable to Mandarin Chinese. This result might be explained by the structure of the material which lacks the complex $\mathrm{C}$ sequences that are typical of German. As concerns our learners, the results are roughly comparable to those depicted in Figure 1: Again, high values for both rhythm metrics were measured for all learners, but the monolingual Mandarin Chinese group (dark grey circles) displays a lower vocalic variability than the majority of the monolingual German learners (light grey squares) and thus performs more target-like. Concerning $\% \mathrm{~V}$, the monolingual Germans appear to be located further left as compared to the other learner groups. For VarcoV, the range of the multilinguals (black triangles) is slightly larger than for the other two groups. Their results once again take an intermediate position between the two monolingual control groups, with some speakers performing better than others do. 
Figure 2: \%V and VarcoV for the CV sentences.
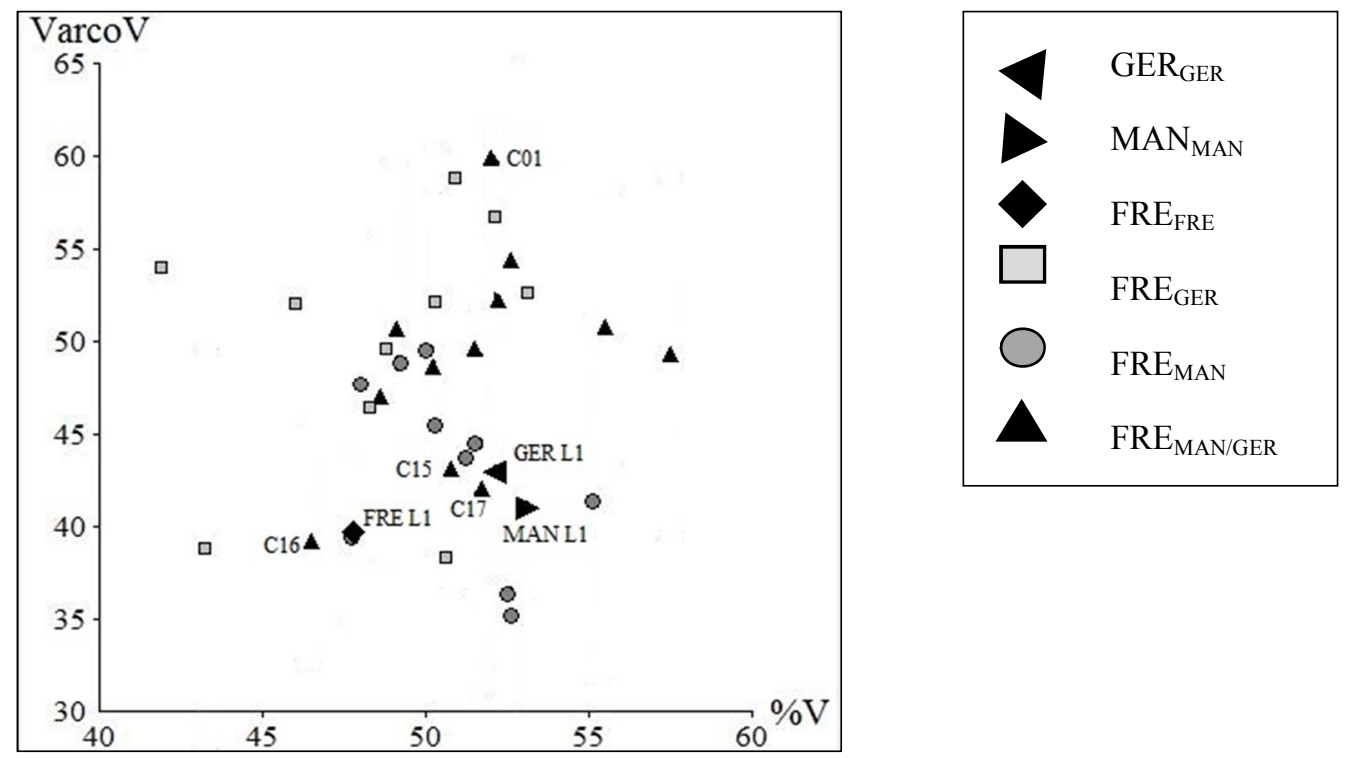

Concerning the results for the nonce words (Figure 3), the general picture is similar to the preceding one in that the German L1 value is situated in between Mandarin Chinese and French. The values for Mandarin have increased regarding $\% \mathrm{~V}$ and decreased for VarcoV; French shows to be stable. The distribution of the learner groups corresponds to the one found for both the read text and the CV sentences: Both groups of monolingual speakers (Mandarin: dark grey circles; German: light grey squares) are set apart from each other while the multilingual values (black triangles) range in between. Once again, some of the multilingual learners attain the French target value more successfully than others.

Figure 3: \%V and VarcoV for the nonce words.

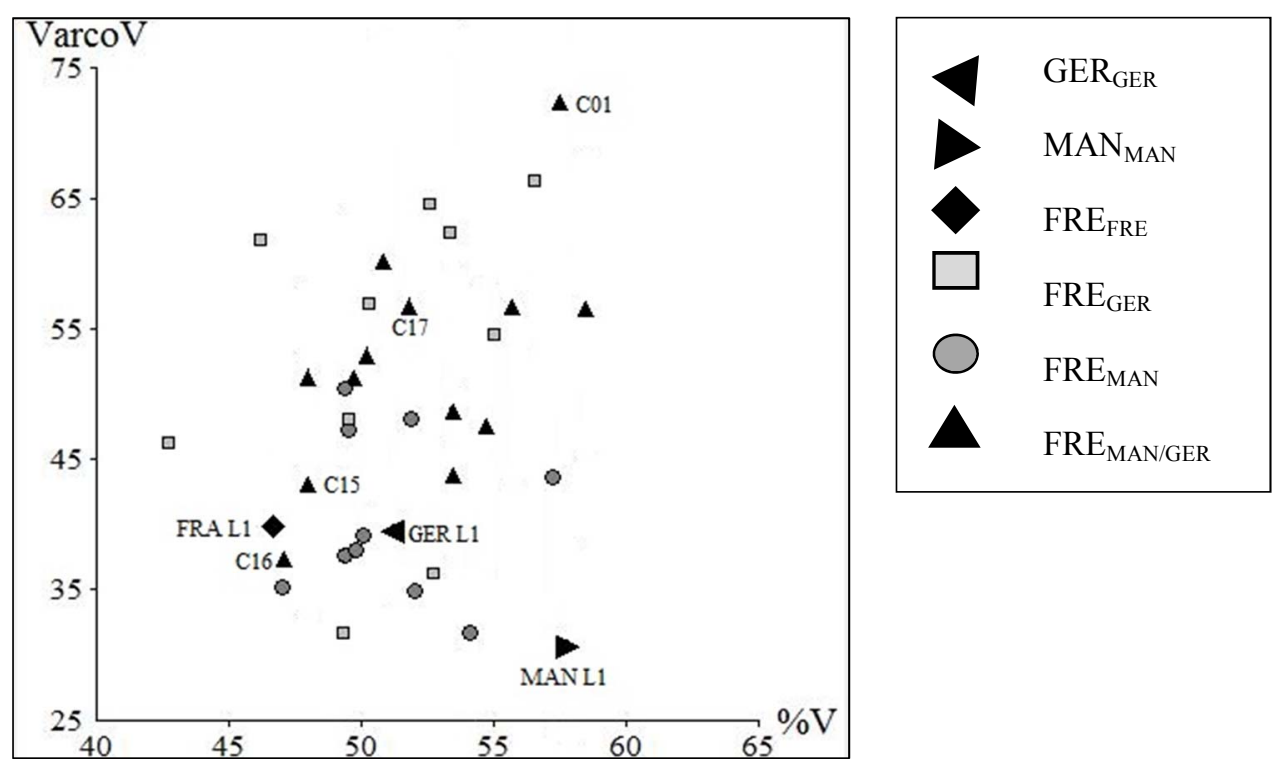


In an overall comparison of the three types of material, the values for the multilingual learners appear in between those of the two monolingual groups in all of the cases. More generally, the range of VarcoV constantly increases for all three groups, while the range of $\% \mathrm{~V}$ is more stable.

Turning now to the extra-linguistic data, the language profiles of selected multilingual learners depicted in Figure 4 (which correspond to the ones highlighted in Figures 1-3), again demonstrate the linguistic diversity that characterizes this group of informants. Learner C01 (female, age: 17) was born in China and came to Germany at the age of nine. At that time, she did not speak any German and so had to learn it as an L2. She then started learning English at the age of ten and French at the age of eleven. C15 (female, age: 15) also was born in China and acquired Shànghai huà as an L1. After having moved to Germany, she acquired both German and Mandarin (AoL: 3) since her parents considered Mandarin to be more useful to her. At school, she learned English (AoL: 8), French (AoL: 11), and Spanish (AoL: 13). Learner C16 (female, age: 17) shows a quite rich language profile: She was born in China where she acquired Mandarin Chinese as her native tongue, and thus might have a quite strong Mandarin background, like $\mathrm{C} 01$ and $\mathrm{C} 15$. At the age of five, her family moved to Russia where she started learning Russian as the first stress-timed language she got in contact with; until now, she occasionally practices this language with her father. One year after having moved to Russia, she started English lessons at school (AoL: 6). At the age of nine, she moved to Germany with her family and started learning German. She continued learning English at school and started French at the age of eleven; two years later, Spanish was added to her linguistic repertoire as a supplementary foreign language (AoL: 13). As different from the other informants, C17 (female, age: 16) was born in Germany. She learned Mandarin from five years on. At school, she learned English (AoL: 8), French (AoL: 11), and Spanish (AoL: 13). Apart from C01, all learners practice their Mandarin Chinese skills by regularly attending 星期日学校 xīngqīrì xuéxiào ('(Chinese) Sunday school').

Figure 4: Language profiles for learners C01, C15, C16, and C17.

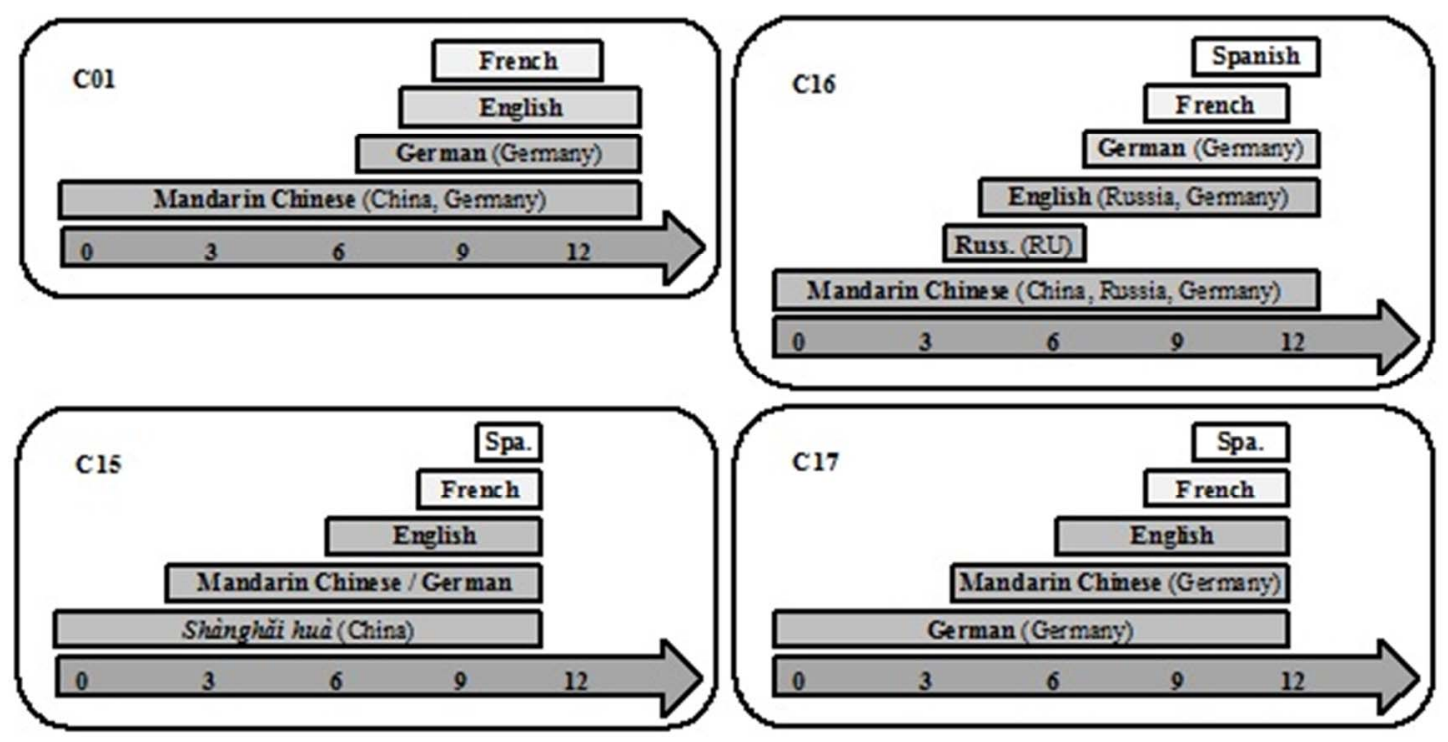

Taking into consideration the individual language profiles, it is rather unexpected that $\mathrm{C} 01$ shows nontarget-like results for French because she seems to have the strongest Mandarin Chinese background in that she grew up as a Mandarin Chinese monolingual until the age of nine and started learning her first stress-timed language (German) relatively late as compared to the other three speakers. So it seems that she has the best prerequisites for (positively) transferring syllable-timed characteristics from her linguistic background to the foreign language French. As for the learners $\mathrm{C} 15$ and $\mathrm{C} 16$, both of them have a comparable language background in that they speak three syllable-timed languages and have a Chinese variety as their L1 (Shànghăi huà or Mandarin). It might seem more expectable that they produce quite 
target-like values in the foreign language French, but this only holds true for C15. One can suspect that for C16, her early L2 Russian may have stabilized a stress-timed language background. Finally, C17 is the only speaker who acquired German as a native tongue and Mandarin Chinese as an early L2, so one could expect her to be less successful in producing French speech rhythm. However, she consistently performs neither very target-like nor absolutely non-target-like. Comparing the interviews of our four speakers clarifies the puzzling results presented so far.

C01: Ich glaub, da ich jetzt in Deutschland lebe, ist es natürlich sinnvoller, wenn ich gut Deutsch kann ... [Chinesisch] hat jetzt gar keinen richtigen Einfluss darauf, wie ich jetzt (.) (...) Französisch lerne.

"I think, because I live in Germany now, that it is more useful for me to speak German quite well ... [Chinese] doesn't have any influence on my way of learning ... French."

Interviewer: [...] Welche Sprachen sind für dich nahe zusammen und welche Sprachen sind also entfernter? C01: [Frage missverstanden] Also, ich glaube (.) auf jeden Fall Deutsch und danach kommt dann glaub ich Chinesisch, weil das sozusagen mit meiner Familie sozusagen verbunden ist und dann Englisch und dann als letzter vielleicht noch andere Sprachen, wie z.B. Französisch.

"Interviewer: Which languages do you feel to be closer together or farther away from each other? C01: [misunderstood question] I think German in any case, then we have Chinese because I think it is linked to my family, then English and at last probably other languages like French for example."

As the interview reveals, $\mathrm{C} 01$ does not consider Chinese to be influential on her way of learning French as opposed to the surrounding language German. Although Mandarin is her L1, she considers German to be much more important. Furthermore, the questionnaire reveals that she never attended Chinese Sunday school. It is striking that she quit French courses as soon as possible and that it has the lowest priority for her. There is no clear evidence of phonological or multilingual awareness.
C15: [Zuordnung der Sprachen zu Körperteilen (Legutke \& Lortz 2002)] Also einfach Chinesisch und Deutsch so im Herz und auch wenn ich was denke ist halt auch auf Chinesisch und Deutsch. Ins Gehirn wollt ich jetzt eher die Fremdsprachen setzen.
"[assigning languages to parts of body] Chinese and German to the heart; even when I think it is in Chinese and German. The foreign languages rather to the brain."
C15: Manche Sprachen klingen so gesanglicher, z. B. Italienisch, manche bisschen abgehackt ... Ich glaub, dass es da eine Verbindung gibt zu Musik.
"Some languages sound like singing, e.g., Italian, others more choppy ... I think there is a link to music."

C15 shows in the interview that she seems to be emotionally attached to both Mandarin Chinese and German, whereas her foreign languages seem to only serve functional purposes. She also displays some proof of phonological and multilingual awareness, e.g., by comparing two different groups of languages regarding their melodic properties, which might refer to what is understood by speech rhythm (klingen so gesanglicher 'sound like singing' vs. abgehackt 'choppy').

C16: Viele können diese Töne nicht so gut und manche Aussprachen nicht so gut, weil die Zunge, also mir ist aufgefallen, bei Sprache ist Zunge ganz wichtig.

"Many people produce the tones and some pronunciations not very well because of the tongue. I noticed that the tongue is very important for languages."

C16: Also wenn ich eine Sprache wie Französisch spreche und da Wörter kommen, die auf anderen Sprachen es auch gibt, denke ich sofort daran, wie man das auf Deutsch, auf Englisch, auf Russisch, auf Spanisch aussprechen könnte. Das heißt, die folgen gleich darauf mit dran und alle verbunden, ja.

"When I speak a language like French, and there are words which also exist in other languages, I immediately think of how they are pronounced in German, in English, in Russian, in Spanish; that is, they directly follow each other and are all interrelated."

C16 does not show any particular affection to a special language, but seems to be interested in any of the languages she has at her disposal. As compared with the other learners, her commentary on the 
importance of the tongue for the production of speech sounds reveals a high degree of phonological awareness, in particular as concerns articulatory phonetics. In addition, she refers to prosodic characteristics such as Chinese lexical tones that might pose problems to L2 learners. Regarding her own strategies of FLL, she refers to cross-linguistic interrelations on the lexical level, thus showing a certain degree of multilingual awareness.

C17: Manche sagen ja, dass Deutsch so eine abgehackte Sprache ist. Und dass es nicht so eine Melodie hat zum Beispiel wie das Französische ... Also wenn man sagt, dass Deutsch nicht so eine Melodie hat, dann kann man auch sagen, dass dann die Deutschen, die Chinesisch lernen, nicht diese Melodie hinbekommen.

"Some people say that German is a choppy language. And that it is not as melodic as French. And if one says that German doesn't have such a melody, you can also assume that Germans who learn Chinese don't succeed in getting this melody." C17: Wörter klingen oft gleich. Also die haben oft nen gleichen Stamm. Weil sie alle glaube ich vom Lateinischen irgendwie kommen. Und ähm ja zum Beispiel so was wie Stern und star und estrella und étoile und so, ist ja relativ gleich. Und ähm ja also es ist schon leichter, sich das zu merken, wenn es gleich klingt, aber ich schaffe es dann trotzdem eigentlich, das zu trennen. Also auch zum Beispiel, wenn es mir auf Spanisch nicht einfällt, dann weiß ich 'Okay, es heißt étoile auf Französisch. Das war doch auch so was in der Art.' Und dann weiß ich es dann irgendwie doch wieder.

"Words often sound alike. Well, they often have the same stem. Because I think they all derive from Latin in a way. For example words like Stern and star and estrella and étoile and so on are relatively similar. And, well, it is easier to remember them when they sound alike but I still manage to separate them. Also, for example, when I can't think of it in Spanish, I know 'Okay, it's étoile in French. That was something of that kind, too.' And then I somehow remember it again."

Finally, the interview conducted with $\mathrm{C} 17$ does not show evidence that she prioritizes any particular language over another. She exhibits a certain degree of phonological and multilingual awareness by comparing the tonal differences between her languages and by reflecting on the consequences this might have for learners. Concerning metalinguistic awareness, she describes how her languages are interrelated to each other on the lexical level and how this helps her learn vocabulary.

The results of the think-aloud protocols are in accordance with the findings on phonological awareness from the interviews. With their comments, the learners were able to confirm this in the protocols although the individual results vary (see Table 2): $\mathrm{C} 15$ and $\mathrm{C} 17$ make comments on five categories. While C15 mentions all categories in both languages, C17 does so only for two criteria. C16 evokes all the categories, mostly in both French and English.

Table 3: Results of the think-aloud protocols for speakers C15, C16, and C17. (FRE refers to comments on French, ENG to comments on English).

\begin{tabular}{|l|l|l|l|}
\cline { 2 - 4 } \multicolumn{1}{c|}{} & C15 & C16 & C17 \\
\hline Segment production & ENG, FRE & ENG, FRE & ENG, FRE \\
\hline Written/spoken distinction & & ENG, FRE & \\
\hline Segment clusters & & FRE & ENG \\
\hline Intonation & ENG, FRE & ENG, FRE & ENG, FRE \\
\hline Word stress & ENG, FRE & ENG & \\
\hline Sentence stress / information structure & & ENG, FRE & \\
\hline Rhythm & & FRE & \\
\hline Prosodic processes & ENG, FRE & FRE & FRE \\
\hline Further prosodic parameters & ENG, FRE & ENG, FRE & ENG \\
\hline
\end{tabular}




\subsection{Discussion: Matching linguistic and non-linguistic data}

The results obtained from the analysis performed on the French speech data display high values for both $\% \mathrm{~V}$ and $\mathrm{Varco} \mathrm{V}$ in all the learner data. We interpret this finding as an effect of low proficiency leading to variable (and usually lower) speech rate and higher occurrences of hesitation phenomena. Compared to their monolingual German counterparts, the monolingual Chinese learners generally produce French speech rhythm more target-like. The group of the multilingual speakers displays inconsistent results intertwined with both monolingual groups. Turning back to our hypotheses, we can conclude that $\mathrm{H} 1$ is only partially confirmed, in that not all of the multilingual learners perform better than the monolingual German learners of French. As shown by means of selected extracted passages from the semi-focused interviews and the results of the think-aloud protocols, the non-linguistic data reveal that the learners' phonological and multilingual awareness as well as their attitudes towards their languages seem to have an influence on the production of speech rhythm in the foreign language: $\mathrm{C} 01$ has a positive attitude towards German. She does not show a high level of phonological awareness; her preference of stresstimed German could lead to a successful production of speech rhythm in her first foreign language English rather than in French. C15 values both Chinese and German and also displays some degree of phonological awareness. The fact that a Chinese variety (Shànghăi huà) is her L1 possibly supports her target-like production of French speech rhythm. Learner C16 appears to appreciate languages and their usefulness in general and additionally shows a relatively high degree of both multilingual and phonological awareness. Interestingly enough, her production of French speech rhythm is very target-like, which may indicate that a positive attitude towards Chinese might favor positive transfer of the syllabletimed speech rhythm of the HL to the syllable-timed foreign language. Finally, C17 does not seem to favor any specific language but shows a fairly high degree of phonological and multilingual awareness. Her tendency towards successful speech rhythm production in French nicely patterns with these nonlinguistic factors. The overall inconsistent picture of the results obtained from the rhythmic analyses performed on the speech data therefore becomes much clearer when taking extra-linguistic aspects into account. With regard to our hypotheses, we can thus conclude that $\mathrm{H} 2$ is confirmed.

All things considered, the remarkable interplay between more or less target-like foreign language production and extra-linguistic factors at least partly explains the diverse multilingual learner data: Both the learners' positive attitudes towards the languages of the sample (i.e., the foreign language French, German, and the HL Mandarin Chinese) and a high degree of multilingual as well as phonological awareness seem to enhance positive transfer of timing patterns from a previously acquired language to a foreign language that exhibits the same rhythmic properties.

\section{Concluding remarks}

Based on the analyses performed on non-native French data produced by different groups of multilingual and monolingual learners, we have shown that both linguistic and extra-linguistic factors constrain crosslinguistic influence with respect to timing patterns. The complex interplay between rhythmic similarities and differences on the one hand and language attitudes as well as metalinguistic and phonological awareness on the other under certain circumstances shows to be advantageous for the multilingual learners with HL Mandarin Chinese as opposed to the German monolinguals when learning French, given that the rhythmic properties of their background languages can be positively transferred to the foreign language. The interrelations between the extra-linguistic data taken from the questionnaire, the semifocused interviews, and the think-aloud protocols and the (more or less target-like) production of speech rhythm in the foreign language suggest that positive transfer is favored by the learners' language attitudes as well as by their individual degree of multilingual and phonological awareness. This shows that a typologically distant language as part of a complex linguistic background does not impose a disadvantage on FLL. Quite the reverse, having syllable-timed Mandarin Chinese as a HL along with the (stress-timed) German language in their linguistic repertoire rather is an advantage - provided that the relevant properties of their background languages get 'activated' in order to serve as a basis for positive transfer of timing patterns. We interpret our findings as evidence to suggest that multilingual and phonological 
awareness should be promoted in scholar education, regarding both learners and teachers. With respect to the rhythmic parallels between learner and contact varieties, as briefly referred to in section 3, the existence of present-day multilingual classroom settings offers an appropriate and fruitful opportunity to teach prosodic differences of different languages, including contact varieties of French, and to practice metalinguistic and phonological awareness, especially because of the fact that certain properties linked to speech rhythm such as, e.g., syllable duration, qualify as being "highly learnable and teachable" (Setter 2006: 767). In the end, the results of our study speak in favor of an intensified collaboration of linguistics and language pedagogical research in order to better meet the challenges posed by the complex constellations of linguistic and cultural diversity that are daily fare in contemporary multilingual classrooms in Europe.

\section{References}

Abercrombie, D. (1967). Elements of General Phonetics. Edinburgh: Edinburgh University Press

Auer, P. (2001). Silben- und akzentzählende Sprachen. Language Typology and Language Universals. An International Handbook, M. Haspelmath et al (eds), 1391-1399. Berlin: De Gruyter.

Auer, P. \& Uhmann, S. (1988). Silben- und akzentzählende Sprachen. Literaturüberblick und Diskussion. Zeitschrift für Sprachwissenschaft, 7, 214-259.

Benet, A., Gabriel, C., Kireva, E. \& Pešková, A. (2012). Prosodic transfer from Italian to Spanish: Rhythmic Properties of L2 Speech and Argentinean Porteño. Proceedings of Speech Prosody 2012, Q. Ma, H. Ding \& D. Hirst (eds). Shanghai, China: Tongji University Press.

Boersma, P. \& Weenink, D. (2011). Praat: Doing phonetics by computer (Version 5.3).

Boula de Mareüil, P. \& Vieru-Dimulescu, B. (2006). The contribution of prosody to the perception of foreign accent. Phonetica, 63, 247-267.

Chen, H. (2012). Second Language Timing Patterns and Their Effects on Native Listeners' Perceptions. Concentric: Studies in Linguistics, 36, 183-212.

Dasher, R. \& Bolinger, D. (1982). On pre-accentual lengthening. Journal of the International Phonetic Association, $12,58-69$.

Dauer, R.M. (1987). Phonetic and phonological components of language rhythm. Proceedings of the eleventh International Congress of Phonetic Sciences (ICPhS 1987), T.V. Gamkrelidze (ed), 447-450. Talinn, Estonia: Academy of Sciences of the Estonian SSR.

Dellwo, V. (2006). Rhythm \& Speech Rate: A variation coefficient for deltaC. Language and Language processing, P. Karnowski \& I. Szigeti (eds), 213-241. Frankfurt: Lang.

Dellwo, V. \& Wagner, P. (2003). Relations between language rhythm and speech rate. Proceedings of the 15th International Congress of Phonetic Sciences, M.-J. Solé et al. (eds), 461-474. Barcelona: Casual Productions.

Deterding, D. (2001). The measurement of rhythm: a comparison of Singapore and British English. Journal of Phonetics, 29, 217-230.

Elsner, D. (2007). Hörverstehen im Englischunterricht der Grundschule. Ein Leistungsvergleich zwischen Kindern mit deutscher Muttersprache und Deutsch als Zweitsprache. Frankfurt: Lang.

Elsner, D. (2010). 'Ich habe was, was du nicht hast ...' Oder: Welchen Mehrwert hat die Mehrsprachigkeit für den Fremdsprachenunterricht? IMIS Beiträge Themenheft, 37, 99-119.

Fagyal, Z. (2010). Accents de banlieue: aspects prosodiques du français populaire en contact avec les langues de l'immigration. Paris: L'Harmattan.

Fagyal, Z., Kibbee, D. \& Jenkins, F. (2006). French. A Linguistic Introduction. Cambridge: CUP.

Fletcher, J. (2010). The Prosody of Speech: Timing and Rhythm. The Handbook of Phonetic Sciences. $2^{\text {nd }}$ edition, W.J. Hardcastle, J. Laver \& F. E. Gibbon (eds), 523-602. Malden: Wiley-Blackwell. 
Gabriel, C., Hu, A., Diao, L. \& Thulke, J. (2012). Transfer, phonological awareness und Mehrsprachigkeitsbewusstsein: Zum Erwerb des französischen Sprachrhythmus durch Schüler/innen mit chinesischem Sprachhintergrund im deutschen Schulkontext. Zeitschrift für Fremdsprachenforschung, 23, 53-76.

Gabriel, C. \& Kireva, E. (2014, to appear). Prosodic transfer in learner and contact varieties: Speech rhythm and intonation of Buenos Aires Spanish and L2 Castilian Spanish produced by Italian native speakers. Studies in Second Language Acquisition, 36.

Grabe, E. \& Low, E.L. (2002). Durational variability in speech and the rhythm class hypothesis. Papers in LabPhon, 7, C. Gussenhoven \& N. Warner (eds), 515-546. Berlin: De Gruyter.

Gussenhoven, C. (2004). The Phonology of Tone and Intonation. Cambridge: CUP.

Gut, U. (2012). Rhythm in L2 speech. Speech and Language Technology (Speech and Language Technology (Technologia Mowy i Języka), 14/15, 83-94.

Hu, A. (2011). Migrationsbedingte Mehrsprachigkeit und schulischer Fremdsprachenunterricht. Forschung, Sprachenpolitik, Lehrerbildung. Umgang mit Heterogenität und Differenz, H. Faulstich-Wieland (ed), 121-140. Scheider: Hohengehren.

Jian, H.-L. (2004). On the Syllable Timing in Taiwan English. Proceedings of Speech Prosody 2004, K. Hirose (ed), 247-250. Nara, Japan.

Jouvet, L. (2006). Les petites histoires d'Amandine. Stuttgart: Klett.

Jun, S.-A. \& Fougeron, C. (2000). A Phonological Model of French Intonation. Intonation. Analysis, Modelling, and Technology, A. Botinis (ed), 209-242. Dordrecht: Kluwer.

Kehoe, M., Lleó, C. \& Rakow, M. (2011). Speech Rhythm in the Pronunciation of German and Spanish Monolingual and German-Spanish Bilingual 3-Year-Olds. Linguistische Berichte, 227, 323-352.

Krivokapić, J. (2013). Rhythm and convergence between speakers of American and Indian English. Laboratory Phonology, 4, 39-65.

Kupisch, T., Snape, N. \& Stangen, I. (2013). Foreign language acquisition in heritage speakers. The acquisition of articles in L3-English by German-Turkish bilinguals. Linguistic Superdiversity in Urban Areas: Research approaches, J. Duarte \& I. Gogolin (eds), 99-122. Amsterdam: Benjamins.

Kurpaska, M. (2010). Chinese language(s): A look through the prism of The Great dictionary of modern Chinese dialects. Berlin: De Gryuter.

Kvale, S. (2007). Doing Interviews. Los Angeles: Sage.

Legutke, M. \& Lortz, W. (eds). (2002). Mein Sprachenportfolio: Entstanden aus einem Pilotprojekt des Landes Hessen, gefördert mit Mitteln des Hessischen Kultusministeriums. Frankfurt am Main: Diesterweg.

Lehiste, Ilse. (1970). Suprasegmentals. Cambridge, MA: MIT Press.

Li, A. \& Post, B. (2012). L2 rhythm development by Mandarin Chinese learners of English. Poster presented at Perspectives on Rhythm and Timing (PoRT), University of Glasgow, 20 July.

Lin, H. \& Wang, Q. (2007). Mandarin rhythm: An acoustic study. Journal of Chinese Linguistics and Computing, 17, $127-140$

Lin, Y.-H. (2007). The Sounds of Chinese. Cambridge: CUP.

Low, E.L., Grabe, E. \& Nolan, F. (2000). Quantitative Characterizations of Speech Rhythm: Syllable-Timing in Singapore English. Language and Speech, 43, 377-401.

Mairano, P. \& Romano, A. (2010). Un confronto tra diverse metriche ritmiche usando Correlatore. La dimensione temporale del parlato, S. Schmid et al. (eds), 79-100. Torriana: EDK.

Martinez, H. \& Reinfried, M. (eds). (2006). Mehrsprachigkeitsdidaktik gestern, heute und morgen. Tübingen: Narr.

Mehler, J., Dupoux, E., Nazzi, T. \& Dehaene-Lambertz, G. (1996). Coping with linguistic diversity: The infant's viewpoint. In Signal to syntax: Bootstrapping from speech to grammar in early acquisition, J.L. Morgan \& K. Demuth (eds), 101-116. Mahwah, NJ: Erlbaum. 
Mehlhorn, G. (2008). Russisch nach Englisch, Polnisch nach Russisch. Überlegungen zu einer Mehrsprachigkeitsdidaktik der slavischen Sprachen aus phonetischer Sicht. XIV. JungslavistInnentreffen in Stuttgart, L. Geist \& G. Mehlhorn (eds), 117-145. München: Kubon \& Sagner.

Meißner, F.-J. \& M. Reinfried. (1998). Mehrsprachigkeitsdidaktik. Konzepte, Analysen, Lehrerfahrungen mit romanischen Fremdsprachen. Tübingen: Narr.

Mok, P. \& Dellwo, V. (2008). Comparing Native and Non-native Speech Rhythm Using Acoustic Rhythmic Measures: Cantonese, Beijing Mandarin and English. Proceedings of the 4th Conference on Speech Prosody, P. Barbosa et al. (eds), 423-426. Campinas, Brazil: Editoria RG/CNPq.

Odlin, T. (1989). Language Transfer. Cambridge: CUP.

Odlin, T. (2003). Cross-Linguistic Influence. The Handbook of Second Language Acquisition, C.J. Doughty \& M.H. Long (eds), 436-486. London: Blackwell.

Ordin, M., Polyanskaya, L. \& Ulbrich, C. (2011). Acquisition of timing pattern in second language. Proceedings of Interspeech 2011, P. Cosi et al. (eds), 27-31. Florence, Italy.

Osburne, A.G. (2003). Pronunciation strategies of advanced ESOL learners. International Review of Applied Linguistics in Language Teaching, 41, 131-141.

Pike, K.L. (1945). The intonation of American English. Ann Arbor: University of Michigan Press.

Pulzován de Egger, S. (2002). Fremdsprache und Rhythmus. Eine Untersuchung zum Sprachrhythmus in Deutsch und Spanisch als Fremdsprache. Marburg: Tectum.

Ramus, F., Nespor, M. \& Mehler, J. (1999). Correlates of linguistic rhythm in the speech signal. Cognition, 73, 265-292.

Rauch, D.P., Jurecka, A. \& Hesse, H.G. (2010). Für den Drittspracherwerb zählt auch die Lesekompetenz in der Herkunftssprache. Migration, Identität, Sprache und Bildungserfolg, C. Allemann-Ghionda et al. (eds), 78-100. Weinheim: Beltz.

Roach, P. (1982). On the distinction between 'stress-timed' and 'syllable-timed' languages. Linguistic controversies, D. Crystal (ed), 73-79. London: Arnold.

Sağin Şimşek, S. Ç. (2006). Third Language Acquisition: Turkish-German Bilingual Students' Acquisition of English Word Order in a German Educational Setting (Mehrsprachigkeit 17). Münster: Waxmann.

Schmidt, C. (2010). Sprachbewusstheit und Sprachlernbewusstheit. Deutsch als Fremd- und Zweitsprache. Ein internationales Handbuch, H.-J. Krumm et al. (eds), 858-866. Berlin: De Gruyter.

Setter, J. (2006). Speech Rhythm in World Englishes: The Case of Hong Kong. TESOL Quarterly, 40, 763-782.

White, L. \& Mattys, S.L. (2007). Calibrating rhythm: First language and second language studies. Journal of Phonetics, 35, 501-522.

Wiese, R. (1996). The Phonology of German. Oxford: Oxford University Press.

\footnotetext{
${ }^{1}$ A positive effect of cross-linguistic awareness on FLL has been evidenced in several studies; see Schmidt (2010) for an overview and Mehlhorn (2008) on phonological learning.

${ }^{2}$ As different from inflecting languages, which indicate grammatical functions by means of affixes on lexical stems (or by stem allomorphy), the words of isolating languages do not undergo any systematic changes.

${ }^{3}$ Since we concentrate on prosodic phonology, the segmental level will not be taken into account. Regarding the phonemic inventories of the languages of our sample, we refer to Lin (2007: 19-82) for Mandarin Chinese, to Wiese (1996: 9-26) for German, and to Fagyal et al. (2006: 23-52) for French.

${ }^{4}$ Note that French and German intonation differ as for the association of tonal targets to the levels of the prosodic hierarchy: While in German F0 marks lexical stress (and thus refers to the syllabic level), French intonational contours depend on the prosodically higher level of groupes rythmiques / Accentual Phrases (Jun \& Fougeron 2000).
} 


\footnotetext{
${ }^{5}$ A third group of languages (e.g., Japanese) are characterized by a regular pacing with respect to the mora as the basic timing unit. This aspect will be disregarded in the following since none of the languages addressed in our study qualifies as being mora-timed (see Fletcher 2010: 529, 553-555).

${ }^{6}$ In a sequence such as la haine 'the hatred' [la.en] the two vowels [a] and [ع] form a single V interval, despite the intervening syllabic boundary.

${ }^{7}$ The learners were also recorded in their first foreign language English. These data, however, are not analyzed for the present purpose.

${ }^{8}$ In accordance with White \& Mattys (2007), the boundaries between V and C intervals were set at the point of zero crossing of the waveform based on formant structure and pitch period. Pre-pausal and phrase-final intervals were considered for the analysis because possible effects of phrase-final lengthening (as in French) were likely to be reflected in the measures. Following Grabe \& Low (2002), we treated glides as belonging to the V intervals if there was no friction attested. For plosives and affricates following a pause, the beginning was placed at 50ms before the burst, given that their boundaries cannot be determined based of the criteria mentioned so far (Mok \& Dellwo 2008).

${ }^{9}$ In order to identify personal attitudes towards the languages, one means used in the interview was the assignment of languages to body parts in a schematic representation of a human being taken from a language portfolio used in foreign language teaching (Legutke \& Lortz 2002).
} 